\title{
Dampak Rasio Keuangan Dan Pandemi COVID-19 Terhadap Kinerja Keuangan
}

\author{
Villy ${ }^{1}$ dan Nuryasman $\mathbf{M N}^{* 2}$ \\ ${ }^{1,2}$ Fakultas Ekonomi dan Bisnis, Universitas Tarumanagara \\ Email Addres: \\ villy.115170157@stu.untar.ac.id \\ *Coressponding Author, Email: nuryasman@ fe.untar.ac.id
}

\begin{abstract}
This study has purpose to determine the effect of ratios on financial performance by using current ratios, quick ratios, dan debt to assets ratios as measuring instruments for the dependent variablesl and using return on assets as measuring instruments for independent variables. The population of the financial statements is PT Multisport Indonesia for the 2019-2021 period. The sampling technique is purposive sampling. The analytical methods to test the hypothesis is path analysis. Data processing using Eviews10 software. The result of the study found that current ratio had a significant positive effect on return on assets, the quick ratio had a significant negative effect on return on assets, and the debt on assets ratio had an insignificant negative effect on return on assets.
\end{abstract}

Keywords: Current Ratio, Quick Ratio, Debt to Assets Ratio, Return on Assets.

Abstrak: Penelitian bertujuan untuk mengetahui pengaruh rasio keuangan terhadap kinerja keuangan dengan menggunakan rasio lancar, rasio cepat, dan debt to assets ratio sebagai alat ukur variabel dependennya dan menggunakan return on assets sebagai alat ukur variabel indenpenden. Populasinya laporan keuangan PT Multisport Indonesia periode 2019-2021. Teknik pengambilan sampel adalah purposive sampling. Metode analisis untuk menguji hipotesis adalah analisis jalur. Pengolahan data menggunakan software Eviews 10. Hasil peneilitian menemukan current ratio berpengaruh positif signifikan terhadap return on assets, quick ratio berpengaruh negatif signifikan terhadap nilai return on assets, debt on assets ratio berpengaruh negatif tidak signifikan terhadap return on assets.

Kata Kunci: Current Ratio, Quick Ratio, Debt to Assets Ratio, Return on Assets.

\section{PENDAHULUAN}

Pandemi COVID-19 memberikan dampak yang menghancurkan berbagai aspek kehidupan masyarakat. Tidak terbatas pada kesehatan, telah mengganggu stabilitas ekonomi dan menggeser kegiatan pendidikan dan sosial budaya (Nuryasman et al., 2020). Salah satu perusahaan yang terkena dampak yaitu PT Multisport Indonesia yang mengalami penurunan permintaan. Agar dapat mengamati perubahan jumlah permintaan maka perusahaan lebih baik mengamati kinerja perusahaan. Maka dari itu perusahaan lebih baik membuat laporan keuangan perusahaan secara berkala. Laporan keuangan adalah laporan yang menunjukkan 
kondisi keuangan perusahaan pada saat ini atau suatu periode tertentu. Laporan keuangan yang diterbitkan oleh perusahaan merupakan cerminan dari kinerja keuangan perusahaan, laporan keuangan merupakan hasil akhir dari proses akuntansi yang disusun dengan tujuan untuk memberikan informasi keuangan bagi suatu perusahaan (Kurniati, 2019).

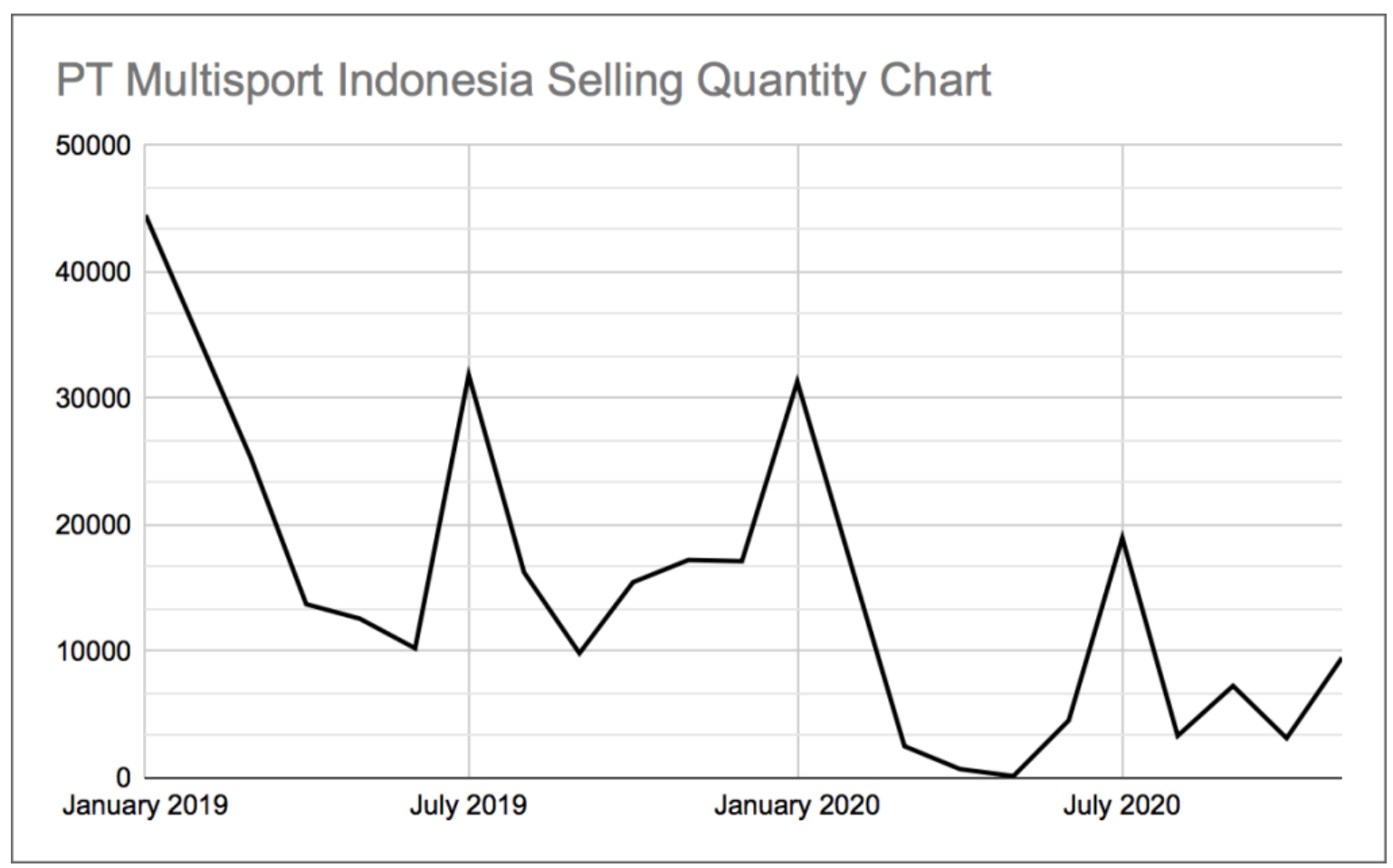

Gambar 1. Tingkat Penjualan PT Multisport Indonesia

Gambar diatas menunjukkan terdapat penurunan penjualan pada PT Multisport Indonesia dari Januari 2020.

Tujuan dari analisis laporan keuangan adalah menunjukkan kepada perusahaan mengenai kondisi keuangan dari perusahaan tersebut dibandingkan dengan rata-rata industri pada saat tertentu berserta opini manajemen atas operasi perusahaan satu tahun terakhir serta prospek perusahaan dimasa yang akan datang dengan melihat kekuatan dan kelemahan perusahaan secara finansial guna dapat melakukan perbaikan serta peningkatan kinerja keuangan. Salah satu hal mudah yang dapat dilakukan saat analisis laporan keuangan adalah membuat rasio keuangan. Rasio keuangan adalah kegiatan membandingkan angka-angka yang ada pada laporan keuangan dengan cara membagi satu angka dengan angka lainnya. Penggunaan dan penerapan rasio keuangan adalah untuk mempermudah saat membaca data keuangan yang kompleks, dan mempermudah saat melakukan analisis keuangan.

Terdapat lima jenis rasio keuangan yang sering digunakan, yaitu rasio likuiditas, rasio aktivitas, rasio leverage, rasio profitabilitas, dan rasio nilai pasar. Salah satu metode yang paling umum untuk analisis keuangan adalah analisis rasio (Dalnial et al., 2014). Menurut penelitian Halimahton Borhan, Rozita Naina Mohamed, dan Nurnafisah Azmi (Borhan et 
al., 2014) bahwa semua variable independen yang meliputi rasio likuiditas, rasio leverage dan rasio profitabilitas berpengaruh pada kinerja keuangan suatu perusahaan.

Penelitian ini mempunyai tujuan untuk mengetahui pengaruh rasio likuiditas terhadap kinerja PT Multisport Indonesia, untuk mengetahui pengaruh rasio leverage terhadap kinerja keuangan PT Multisport Indonesia, dan untuk mengetahui pengaruh COVID-19 terhadap kinerja keuangan PT Multisport Indonesia.

\section{KAJIAN TEORI}

Teori Struktur Modal. dikembangkan oleh Modigliani dan Miller (Franco dan Merton, 1958). Mereka membuktikan bahwa memilih antara hutang dan pembiayaan ekuitas tidak mempengaruhi nilai perusahaan, maka dari itu perusahaan lebih baik berhenti mengkhawatirkan proporsi efek hutang dan ekuitas karena di pasar modal yang sempurna, kombinasi apa pun dari hutang dan efek ekuitas adalah kombinasi yang bagus seperti yang lain. Struktur modal pada dasarnya berkaitan dengan bagaimana suatu perusahaan membiayai keseluruhan operasi dan kemajuannya dengan memanfaatkan berbagai sumber dana. Dengan kata lain, struktur modal perusahaan merupakan hasil dari serangkaian situasi, yang menggabungkan keputusan pendanaan dari pengusaha, penjatahan kredit penyedia dana dan kondisi pasar.

Terdapat banyak jenis dana yang berbeda tergantung pada kebutuhan keuangan perusahaan. Salah satunya adalah hutang yang dapat dalam bentuk wesel, kredit atau obligasi. Hutang jangka pendek seperti hutang peminjaman modal juga termasuk dalam struktur modal perusahaan. Mungkin karena pembayaran bunga hutang dapat mengurangi pajak. Nilai perusahaan yang berhutang akan melebihi nilai perusahaan tanpa hutang dengan jumlah yang sama dengan nilai sekarang dari penghematan pajak yang timbul dari penggunaan hutang. Selain itu, hutang juga dapat mempertahankan kepemilikan perusahaan tidak seperti ekuitas. Tetapi, ekuitas tidak perlu membayar lagi saat pendapatan menurun seperti hutang.

Pecking Order Theory. Dikenalkan oleh Myers dan Majluf (Stewart, 1984) berdasarkan informasi asimetris dan menandakan masalah dengan pembiayaan eksternal. dan menjelaskan bahwa terdapat hierarki dalam aktivitas pendanaan perusahaan, yaitu preferensi untuk pembiayaan internal dibandingkan pembiayaan eksternal dan untuk pembiayaan hutang daripada pembiayaan ekuitas dalam pembiayaan eksternal.

Menurut teori ini, dana internal tidak memiliki asimetri informasi atau biaya flotasi dan oleh karena itu diprioritaskan daripada pembiayaan eksternal. Ekuitas diterbitkan hanya jika batas kapasitas hutang yang ada habis (Bhama et al., 2016).

Pecking order didorong oleh biaya informasi dan perusahaan besar biasanya memiliki biaya informasi yang rendah. Teori ini diharapkan dapat bekerja lebih baik untuk perusahaan dengan asimetri informasi tinggi seperti perusahaan kecil (Bhama et al., 2016).

Kinerja Keuangan. Menurut (Zainal dan Marlius, 2016), Kinerja perusahaan merupakan suatu gambaran tentang kondisi keuangan suatu perusahaan yang dianalisis dengan alat-alat analisis keuangan, sehingga dapat diketahui mengenai baik buruk nya keadaan keuangan suatu perusahaan yang mencerminkan prestasi kerja dalam periode tertentu. 
Pentingnya penilaian kinerja keuangan perusahaan adalah sebagai berikut: (1) Untuk mengetahui tingkat likuiditas, yaitu kemampuan perusahaan untuk memperoleh kewajiban keuangannya yang harus segera dipenuhi atau kemampuan perusahaan untuk memenuhi keuangannya pada saat ditagih. (2) Untuk mengetahui tingkat solvabilitas, yaitu kemampuan perusahaan untuk memenuhi kewajiban keuangannya apabila perusahaan tersebut dilikuidasi baik kewajiban keuangan jangka pendek maupun jangka panjang. (3) Untuk mengetahui tingkat rentabilitas atau profitabilitas, yaitu menunjukkan kemampuan perusahaan untuk menghasilkan laba selama periode tertentu. (4) Untuk mengetahui tingkat stabilitas usaha, yaitu kemampuan perusahaan untuk melakukan usahanya dengan stabil, yang diukur dengan mempertimbangkan kemampuan perusahaan untuk membayar beban bunga atas hutang-hutangnya termasuk membayar kembali pokok hutangnya tepat pada waktunya serta kemampuan membayar deviden secara teratur kepada para pemegang saham tanpa mengalami hambatan atau krisis keuangan (Samben dan Pattisahusiwa, 2017).

Menurut penjelasan dari indikator-indikator kinerja keuangan, maka peneliti menggunakan indikator yang digunakan pada penelitian (Pokharel et al., 2019) yaitu, return on assets untuk mencari indikator yang terbaik untuk kinerja keuangan. Penilaian kinerja keuangan digunakan untuk mengetahui seberapa jauh efektivitas operasi perusahaan untuk mencapai tujuan perusahaan dan menilai kinerja perusahaan dengan menggunakan analisis rasio yang dimulai dengan menggunakan laporan keuangan yang diperbandingkan, termasuk data tentang perubahan-perubahan yang terjadi dalam perusahaan dalam nominal rupiah, persentasi dan trendnya. (Marginingsih, 2017).

Likuiditas. likuiditas berkaitan dengan kemampuan perusahaan untuk membayar kewajiban jangka pendek yang harus segera dilunasi (Marfianto dan Nuryasman, 2019). Likuiditas merupakan aspek penting dari keseluruhan manajemen perusahaan, yang merupakan faktor keseimbangan antara aset lancar dan kewajiban lancar (Goel et al., 2015). Ini membantu perusahaan untuk menutupi kekurangan kas pada saat kesulitan keuangan dan membiayai peluang investasi yang menguntungkan (Nikolov, 2013). Rasio likuiditas sendiri memiliki pengertian sebagai kemampuan perusahaan membayar kewajiban atau utang jangka pendeknya. Untuk rasio likuiditas, perusahaan harus mengelola aset lancar dan kewajiban lancarnya dengan bijak agar tidak terjadi default payment.

Menurut (Horvath dan Seidler, 2013), untuk menciptakan likuiditas, perusahaan perlu mendanai aset yang relatif tidak likuid dengan liabilitas yang relatif likuid. Risiko likuiditas berasal dari kesulitan atau ketidakmungkinan untuk memasarkan atau menutup investasi dengan cukup cepat untuk mencegah atau meminimalkan kerugian. Secara umum valid bahwa posisi dari ukuran yang lebih kecil tunduk pada risiko likuiditas yang lebih besar (Corelli, 2019).

Manajemen risiko likuiditas bertujuan untuk mencapai dua tujuan utama. Di satu sisi, ia harus menilai, dalam perspektif, pendanaan yang dibutuhkan oleh sebuah lembaga untuk memenuhi kewajiban. Di sisi lain, harus memastikan ketersediaan uang tunai atau agunan untuk memenuhi kebutuhan tersebut pada waktu yang tepat melalui koordinasi sumber pendanaan yang tersedia dalam kondisi normal dan stres (Corelli, 2019). Rasio likuiditas sendiri terdapat 3 jenis yaitu sebagai berikut:

(1) Rasio lancar (current ratio). Rasio yang bertujuan untuk mengukur suatu perusahaan untuk membayar hutang jangka pendeknya. (2) Rasio cepat (quick ratio). Rasio yang 
digunakan untuk mengukur perbandingan kewajiban jangka pendek dan aktiva lancar secara cepat. (3) Rasio Kas (cash ratio). Rasio yang digunakan untuk membandingkan cash flow dengan hutang yang harus dibayar sehingga dapat mengetahui apakah perusahaan berada di posisi berbahaya atau tidak.

Menurut penjelasan dari indikator-indikator likuiditas, maka peneliti menggunakan indikator yang digunakan pada penelitian (Borhan et al., 2014) yaitu, rasio lancar (current ratio) dan rasio cepat (quick ratio). Karena rasio likuiditas merupakan salah satu rasio yang diperlukan saat melakukan analisis pada suatu laporan keuangan perusahaaan, rasio likuiditas merupakan rasio yang menunjukkan kemampuan perusahaan dalam memenuhi kewajiban atau hutang jangka pendek yang harus dipenuhi oleh perusahaan (Widnyana et al., 2020).

Leverage. leverage adalah kemampuan perusahaan dalam penggunaan hutang secara efisien untuk membiayai kegiatan investasi jangka pendek maupun jangka panjang yang dilakukan perusahaan (Marfianto dan Nuryasman, 2019). Untuk memungkinkan sebagian efek non-linier dari leverage pada investasi, kami mendefinisikan tiga kategori leverage, yaitu, rendah (rasio utang 60 persen atau kurang), sedang (rasio utang 60-80 persen) dan tinggi (rasio utang Leverage, investasi dan pemulihan lebih dari 80 persen) (Kuchler, 2020). Rasio Leverage sendiri terbagi menjadi 4 jenis yaitu sebagai berikut:

Rasio hutang terhadap aset (debt to asset ratio). Rasio yang digunakan untuk mengukur kemampuan perusahaan mengandalkan hutang untuk membiayai aset perusahaan.

Rasio hutang terhadap ekuitas (debt to equity ratio). Rasio yang digunakan untuk mengukur hutang terhadap ekuitas perusahaan dengan cara membandingkan seluruh hutang perusahaan dengan seluruh modal dari pemegang saham.

Times interest earned ratio. Rasio yang digunakan untuk mengukur kemampuan perusahaan membayar beban bunga di masa depan. Menurut penjelasan dari indikatorindikator leverage, maka peneliti menggunakan indikator yang digunakan pada penelitian Halimahton (Borhan et al., 2014); (Borhan et al., 2014) yaitu, debt to assets ratio. Leverage dapat dihitung menggunakan proksi debt to assets ratio, karena dengan menggunakan debt to assets ratio ini investor dapat melihat seberapa besar hutang perusahaan yang berpengaruh terhadap pengelolaan aset atau seberapa besar aset perusahaan yang dibiayai oleh hutang (Kasmir, 2016).

COVID. COVID merupakan penyakit menular melalui udara yang telah menyebar keseluruh dunia. COVID atau yang dikenal sebagai corona berawal dari Wuhan, China. Dan mulai masuk di Indonesia pada awal tahun 2020. Tepatnya pada 2 Maret 2020, untuk pertama kalinya pemerintah mengumumkan dua pasien positif Covid-19 di Indonesia (Pranita, 2020).

(H4) : Terdapat pengaruh COVID terhadap return on assets.

Penelitian Relevan. Halimahton Borhan, Rozita Naina Mohamed dan Nurnafisah Azmi (Borhan et al., 2014) dalam "The impact of financial ratios on the financial performance of 
a chemical company The case of LyondellBasell Industries". Menguji pengaruh rasio keuangan terhadap kinerja keuangan sebuah perusahaan kimia: LyondellBasell Industries (LYB). Beberapa rasio yang dipilih: rasio lancar (CR) dan rasio cepat (QR) mewakili rasio likuiditas, rasio utang (DR) dan rasio ekuitas utang (DTER) mewakili rasio leverage, sedangkan margin laba operasi (OPM) dan margin laba bersih (NPM). Pada penelitian dapat ditemukan rasio leverage, rasio likuiditas, dan rasio profitabilita memberikan dampak positif pada kinerja keuangan LyondellBasell Industries.

(Danso et al., 2020). "Leverage and Perfomance: Do Size and Crisis Matter?". Meneliti pengaruh leverage keuangan terhadap kinerja perusahaan dan pengaruh ukuran perusahaan dan masalah krisis dalam hubungan leverage dan kinerja keuangan. Pada penelitian ini ditemukan bahwa ukuran perusahaan mempengaruhi hubungan leverage terhadap kinerja perusahaan dan krisis keuangan tidak mempengaruhi hubungan leverage terhadap kinerja keuangan

(Zeitun dan Saleh, 2015). "Dynamic Performance, Financial Leverage and Financial Crisis: Evidence From GCC Countries". Meneliti pengaruh leverage pada kinerja keuangan di negara Gulf Cooperation Council (GCC). Pada penelitian ini ditemukan bahwa leverage mempengaruhi kinerja keuangan secara signifikan dan krisis keuangan mempengaruhi kinerja keuangan secara signifikan dan negatif di negara-negara GCC.

(Kantakji et al., 2020). "What drives the financial performance of general takaful companies?". Penelitian ini bertujuan untuk mengidentifikasi faktor internal dan eksternal yang mempengaruhi kinerja keuangan perusahaan takaful umum yang beroperasi di Arab Saudi, Malaysia, UEA, Qatar dan Pakistan, dengan menggunakan kumpulan data panel tidak seimbang yang terdiri dari 53 perusahaan. Pada penelitian ini ditemukan bahwa ukuran perusahaan, likuiditas, ketergantungan berulang, PDB per kapita, tingkat pengembalian ekuitas dan tingkat bunga berhubungan signifikan secara statistik dengan kinerja keuangan; ukuran perusahaan, PDB per kapita, return ekuitas dan tingkat bunga berhubungan positif dengan kinerja, sedangkan ketergantungan likuiditas dan retakaful berhubungan negatif dengan kinerja.

Kaitan antara Rasio Likuiditas dan Kinerja Keuangan. (Ida dan Ketut, 2014), menemukan bahwa semakin tinggi likuiditas suatu perusahaan maka kinerja perusahaan akan menurun.

Rasio likuiditas akan mengukur kelancaran pengunaan aset perusahaan untuk menilai kelancaran kinerja perusahaan suatu perusahaan (Tampubolon, 2015).

Menurut penelitian (Borhan et al., 2014). Terdapat hubungan positif antara rasio likuiditas dan kinerja keuangan. Semakin tinggi nilai current rasio maka semakin tinggi pula kemampuan perusahaan untuk membayar hutang dan kewajiban pada saat jatuh tempo dan perusahaan juga dapat menghindari pembiayaan jangka pendeknya untuk meningkatkan pertumbuhan jangka pendek perusahaan.

(Kantakji et al., 2020) menemukan terdapat hubungan yang signifikan antara rasio likuiditas dengan kinerja keuangan. Namun, likuiditas tidak boleh turun di bawah level optimal.

(H1) : Terdapat pengaruh current ratio terhadap return on assets.

(H2) : Terdapat pengaruh quick ratio terhadap return on assets. 
Kaitan antara Rasio Leverage dan Kinerja Keuangan. Rasio Leverage digunakan untuk mengukur tingkat operasi hutang untuk menghindari risiko keuangan, apabila rasio leverage semakin tinggi, sementara nilai aktiva tetap maka total hutang perusahaan akan meningkat yang menyebabkan kinerja perusahaan menjadi tidak lancar (Tampubolon, 2015).

Menurut (Borhan et al., 2014). Terdapat hubungan positif antara rasio leverage dan kinerja keuangan. Semakin tinggi nilai debt to assets ratio maka menunjukkan banyaknya hutang jangka panjang perusahaan dan tingginya kegagalan untuk membayar saat jatuh tempo.

(Zeitun dan Saleh, 2015) Juga menemukan hubungan yang signifikan antara rasio leverage dengan kinerja keuangan, dan menemukan bahwa semakin tinggi nilai rasio leverage maka semakin menurunkan kinerja perusahan.

(H3) : Terdapat pengaruh debt to assets ratio terhadap return on assets.

Kaitan antara COVID dan Kinerja Keuangan. Pandemi COVID-19 memberikan dampak yang besar karena terdapat pembatasan aktivitas masyarakat yang memberikan dampak pada perekonomian. Dengan dibatasinya jam operasional memberikan dampak penurunan pendapatan bagi perusahaan.

(H4) : Terdapat pengaruh COVID terhadap return on assets.

Berdasarkan kaitan diatas, terbentuk kerangka pemikiran dan hipotesis sebagai berikut; 


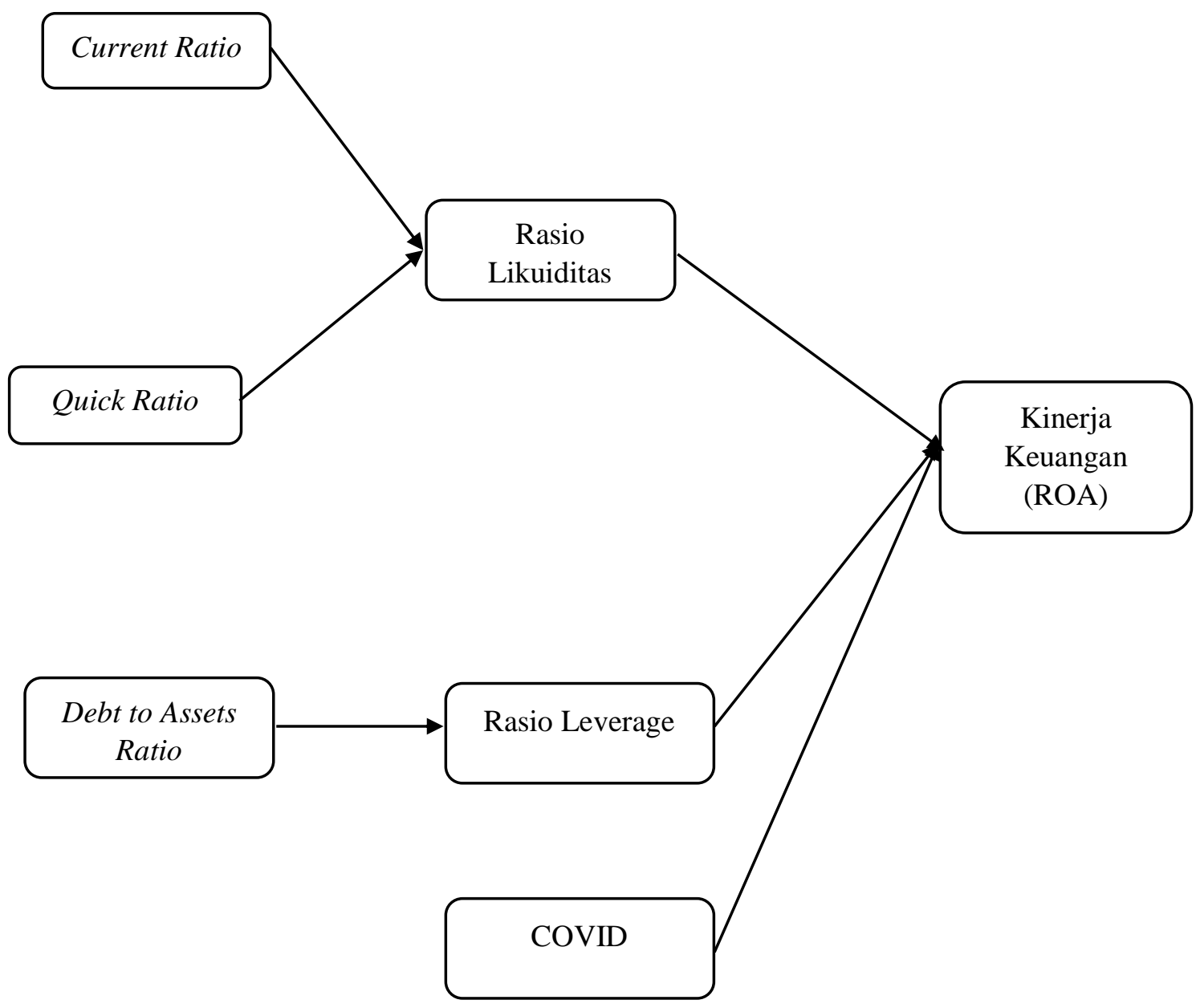

Gambar 2. Model Penelitian

Hipotesis $1(\mathrm{H} 1)$ : Terdapat pengaruh current ratio terhadap return on assets.

Hipotesis $2(\mathrm{H} 2)$ : Terdapat pengaruh quick ratio terhadap return on assets.

Hipotesis 3 (H3) : Terdapat pengaruh debt to assets ratio terhadap return on assets.

Hipotesis 4 (H4) : Terdapat pengaruh COVID terhadap return on assets.

\section{METODOLOGI}

Subyek penelitian ini adalah PT Multisport Indonesia Januari 2019 - Maret 2021. Obyek pada penelitian Kinerja Keuangan dengan alat ukur return on assets sebagai alat ukur sebagai variabel dependen, serta likuiditas dengan menggunakan current ratio dan quick ratio sebagai alat ukur dan leverage dengan menggunakan debt to assets ratio sebagai alat ukur sebagai variabel indenpenden dan disertai COVID sebagai variabel dummy. Operasionalisasi variabel yang di gunakan sebagai berikut: 
Tabel 1. Operasionalisasi Variabel

\begin{tabular}{l|c|l|l|l}
\hline \multicolumn{1}{c|}{ Variabel } & Indikator & Kode & Skala & \multicolumn{1}{c}{ Acuan } \\
\hline Current Ratio & CR $=\frac{\text { aktiva lancar }}{\text { hutang lancar }}$ & CR & Rasio & $\begin{array}{l}\text { (Tampubolon, } \\
2015)\end{array}$ \\
\hline Quick Ratio & $Q R=\frac{\text { aktiva lancar }- \text { persediaan }}{\text { hutang lancar }}$ & QR & Rasio & $\begin{array}{l}(\text { Tampubolon, } \\
2015)\end{array}$ \\
\hline Debt to Asset Ratio & $D A R=\frac{\text { total hutang }}{\text { total aktiva }}$ & DAR & Rasio & $\begin{array}{l}\text { (Tampubolon, } \\
2015)\end{array}$ \\
\hline Return on assets & $R O A=\frac{\text { laba bersih }}{\text { total aset } x 100 \%}$ & ROA & Rasio & $\begin{array}{l}(\text { Mulyawan, } \\
2015)\end{array}$ \\
\hline
\end{tabular}

Metode yang digunakan adalah metode penelitian kuantitatif. Populasinya adalah laporan keuangan PT Multisport Indonesia. Ukuran sampelnya laporan keuangan PT Multisport Indonesia Januari 2019 - Maret 2021. Teknik pengambilan sampel adalah purposive sampling. penelitian menggunakan data sekunder yang diperoleh dari laporan keuangan PT Multisport Indonesia.

\section{HASIL ANALISIS DATA}

Tabel 2. Analisis Statitstik Deskriptif

\begin{tabular}{|c|c|c|c|c|c|}
\hline & ROA & CR & QR & DAR & COVID \\
\hline Mean & 0.04581 & 2.11975 & 1.64479 & 0.51772 & 0.48148 \\
\hline Median & 0.03524 & 2.14261 & 1.66656 & 0.50702 & 0.00000 \\
\hline Maximum & 0.25107 & 3.70400 & 2.70072 & 0.94025 & 1.00000 \\
\hline Minimum & 0.00400 & 1.15106 & 1.01144 & 0.02591 & 0.00000 \\
\hline Std. Dev. & 0.04864 & 0.67852 & 0.52036 & 0.26546 & 0.50918 \\
\hline Skewness & 2.90101 & 0.33810 & 0.14266 & -0.04394 & 0.07413 \\
\hline Kurtosis & 12.8660 & 2.58461 & 1.70742 & 1.88458 & 1.00550 \\
\hline Jarque-Bera & 147.376 & 0.70852 & 1.97120 & 1.40838 & 4.50003 \\
\hline Probability & 0.00000 & 0.70169 & 0.37322 & 0.49451 & 0.10540 \\
\hline Sum & 1.23680 & 57.2333 & 44.4094 & 13.9786 & 13.0000 \\
\hline Sum Sq. Dev. & 0.06152 & 11.9703 & 7.04020 & 1.83222 & 6.74074 \\
\hline Observations & 27 & 27 & 27 & 27 & 27 \\
\hline
\end{tabular}

Berdasarkan tabel 4.1 kita mengetahui nilai rata-rata return on assets selama periode penelitian sebesar 0,04581 yang menunjukkan bahwa kemampuan perusahaan menghasilkan laba rata-rata sebesar $4,58 \%$ dengan nilai terendah return on assets pada penelitian ini sebesar 0,00400 dan nilai tertingginya 0,25107. Nilai standar deviasi return on assets sebesar 0,04864 yang menunjukkan bahwa penyimpangan return on assets pada penelitian ini kurang lebih sebesar 0,04864. 
Nilai rata-rata current ratio yang diperoleh sebesar 2,11975 yang berarti kemampuan perusahaan membayar kewajiban lancarnya baik dimana nilai aset lancarnya lebih besar dibandingkan nilai hutang lancarnya, dengan nilai minimum sebesar 1,15106 dan nilai maksimum sebesar 3,70400. Nilai standar deviasi yang diperoleh sebesar 0,67852 yang berarti nilai penyimpangan current ratio pada penelitian ini kurang lebih sebesar 0,67852.

Hasil analisis statistik deksriptif kita dapat mengetahui nilai rata-rata quick ratio sebesar 1,64479 yang berarti perusahaan dapat membayar hutang lancarnya dengan baik karena nilai aset yang paling liquid lebih besar daripada hutang lancarnya dengan nilai nilai terendahnya sebesar 1,01144 dan nilai tertingginya sebesar 2,70072. Nilai standar deviasi quick ratio sebesar 0,52036 yang berarti penyimpangan quick ratio pada penelitian ini kurang lebih sebesar 0,52036.

Tabel analisis statistik deskriptif diatas kita dapat mengetahui nilai rata-rata debt to assets ratio sebesar 0,51772 yang berarti nilai aset perusahaan dibiayai oleh hutang sebesar 0,51772 dengan nilai 0,02591 dan nilai tertinggi sebesar 0,94025 . Nilai standar deviasi sebesar 0,26546 yang berarti penyimpangan debt to assets ratio pada penelitian ini kurang lebih sebesar 0,26546.

Berdasarkan hasil analisis statistik deskriptif pada tabel diatas kita dapat mengetahui nilai rata-rata COVID sebesar 0,48148 yang berarti rata-rata keberadaan COVID pada penelitian ini sebesar 0,48148. Pada tabel diatas juga menunjukkan nilai minimum COVID sebesar 0,00000 yang berarti tidak ada COVID dan nilai maksimum 1,00000 yang berarti terdapat COVID pada periode tersebut. Nilai standar deviasi COVID yang diperoleh sebesar 0,50918 yang berarti penyimpangan data COVID pada penelitian ini sebesar kurang lebih 0,50918 . 
Tabel 3. Model Regresi Linear

Dependent Variable: ROA

Method: Least Squares

Date: 05/26/21 Time: 13:27

Sample: 2019M01 2021M03

Included observations: 27

\begin{tabular}{lrlrr}
\hline \hline \multicolumn{1}{c}{ Variable } & Coefficient & Std. Error & t-Statistic & Prob. \\
\hline \hline \multicolumn{1}{c}{ C } & 0.127500 & 0.072134 & 1.767554 & 0.0910 \\
CURRENT_RATIO & 0.097222 & 0.028554 & 3.404844 & 0.0025 \\
$\quad$ QUICK_RATIO & -0.151122 & 0.053774 & -2.810300 & 0.0102 \\
DEBT_TO_ASSET_RAT & & & & \\
\multicolumn{1}{c}{ IO } & -0.005741 & 0.029576 & -0.194106 & 0.8479 \\
\multicolumn{1}{c}{ COVID } & -0.075272 & 0.035770 & -2.104319 & 0.0470 \\
\hline \hline R-squared & 0.465762 & Mean dependent var & 0.045807 \\
Adjusted R-squared & 0.368627 & S.D. dependent var & 0.048643 \\
S.E. of regression & 0.038651 & Akaike info criterion & -3.502905 \\
Sum squared resid & 0.032866 & Schwarz criterion & -3.262935 \\
Log likelihood & 52.28921 & Hannan-Quinn criter. & -3.431549 \\
F-statistic & 4.795030 & Durbin-Watson stat & 1.884440 \\
Prob(F-statistic) & 0.006196 & & \\
\hline \hline
\end{tabular}

Tabel koefisien diatas menunjukkan nilai konstant (a) 0,12750, current ratio 0,09722, quick ratio -0,15112, debt to assets ratio -0,00574, dan COVID -0,07527, maka diketahui persamaan regresi sebagai berikut:

$\mathrm{ROA}=\mathrm{a}+\mathrm{bCR}+\mathrm{cQR}+\mathrm{dDAR}+\mathrm{eCOVID}$

$\mathrm{ROA}=0,12750+0,09722 \mathrm{CR}-0,15112 \mathrm{QR}-0,00674 \mathrm{DAR}-0,07527$ COVID

Apabila CR (current ratio), DAR(debt to assets ratio), QR(quick ratio), dan COVID mempunyai nilai sama dengan 0 , maka nilai ROA (return on assets) sebesar 0,12750, dikarenakan nilai konstanta persamaan regresi linear sebesar 0,12750.

Nilai CR (current ratio) sebesar 0,09722 artinya, apabila QR (quick ratio), DAR (debt to assets ratio), dan COVID tidak terdapat perubahan dan CR (current ratio) meningkat satu satuan maka nilai ROA (return on assets) akan meningkat 0,09722 satuan.

Nilai QR (quick ratio) sebesar -0,15112 artinya, apabila CR (current ratio), DAR (debt to assets ratio), dan COVID tidak terdapat perubahan nilai dan QR (quick ratio) meningkat satu satuan maka nilai perusahaan akan mengalami penurunan sebesar 0,15112 satuan.

Nilai DAR (debt to assets ratio) sebesar -0,00674 artinya, apabila CR (current ratio), QR (quick ratio), dan COVID tidak terdapat perubahan dan DAR (debt to assets ratio) meningkat satu satuan maka nilai kinerja perusahaan akan menurun 0,00674 satuan.

Variabel dummy tidak memiliki istilah pengaruh positif atau negatif hanya dapat mengetahui perbedaan yang signifikan pada variabel tersebut (Abdul, 2020). Untuk 
mengetahui perbedaan yang signifikan antara terdapat COVID dan tidak terdapat COVID yaitu, dengan cara COVID ditandai dengan nilai 1 dan tidak terdapat COVID ditandai dengan nilai 0. Berdasarkan persamaan diatas, dapat diketahui nilai COVID sebesar 0,07527 artinya ROA perusahaan saat adanya COVID lebih kecil dibandingkan jika tidak ada COVID.

Tabel 4. Uji T

Dependent Variable: ROA

Method: Least Squares

Date: 05/26/21 Time: $13: 27$

Sample: 2019M01 2021M03

Included observations: 27

\begin{tabular}{lrcrr}
\hline \multicolumn{1}{c}{ Variable } & Coefficient & Std. Error & t-Statistic & Prob. \\
\hline \multicolumn{1}{c}{ C } & 0.127500 & 0.072134 & 1.767554 & 0.0910 \\
CURRENT_RATIO & 0.097222 & 0.028554 & 3.404844 & 0.0025 \\
QUICK_RATIO & -0.151122 & 0.053774 & -2.810300 & 0.0102 \\
DEBT_TO_ASSET_RAT & & & & \\
$\quad$ IO & -0.005741 & 0.029576 & -0.194106 & 0.8479 \\
\multicolumn{1}{c}{ COVID } & -0.075272 & 0.035770 & -2.104319 & 0.0470 \\
\hline \hline & 0.465762 & Mean dependent var & & 0.045807 \\
R-squared & 0.368627 & S.D. dependent var & & 0.048643 \\
Sdjusted R-squared & 0.038651 & Akaike info criterion & & -3.502905 \\
Sum squared resid & 0.032866 & Schwarz criterion & -3.262935 \\
Log likelihood & 52.28921 & Hannan-Quinn criter. & & -3.431549 \\
F-statistic & 4.795030 & Durbin-Watson stat & & 1.884440 \\
Prob(F-statistic) & 0.006196 & & & \\
\hline \hline
\end{tabular}

Berdasarkan Tabel 3 kita mengetahui bahwa nilai probabilitas CR sebesar 0,0025 yang berarti $\mathrm{CR}<0,05$ yang berarti terdapat hubungan yang signifikan antara current ratio dengan ROA. QR mempunyai nilai probabilitas yang diperoleh sebesar 0,0102 yang berarti nilai probabilitas quick ratio $<0,05$ yang berarti terdapat hubungan yang signifikan antara QR dengan ROA. DAR mempunyai nilai probabilitas sebesar 0,8479 yang berarti nilai probabilitas DAR > 0,05 yang berarti tidak terdapat hubungan signifikan antara DAR dan ROA. COVID mempunyai nilai probabilitas sebesar 0,0470 yang menunjukkan terdapat hubungan yang signifikan antara COVID dan ROA karena nilai probabilitas COVID < 0,05. 
Tabel 5. Uji F

Dependent Variable: ROA

Method: Least Squares

Date: 05/26/21 Time: 13:27

Sample: 2019M01 2021M03

Included observations: 27

\begin{tabular}{lrlrr}
\hline \hline \multicolumn{1}{c}{ Variable } & Coefficient & Std. Error & t-Statistic & Prob. \\
\hline \hline C & 0.127500 & 0.072134 & 1.767554 & 0.0910 \\
CURRENT_RATIO & 0.097222 & 0.028554 & 3.404844 & 0.0025 \\
QUICK_RATIO & -0.151122 & 0.053774 & -2.810300 & 0.0102 \\
DEBT_TO_ASSET_RAT & & & & \\
IO & -0.005741 & 0.029576 & -0.194106 & 0.8479 \\
COVID & -0.075272 & 0.035770 & -2.104319 & 0.0470 \\
\hline \hline R-squared & 0.465762 & Mean dependent var & 0.045807 \\
Adjusted R-squared & 0.368627 & S.D. dependent var & 0.048643 \\
S.E. of regression & 0.038651 & Akaike info criterion & -3.502905 \\
Sum squared resid & 0.032866 & Schwarz criterion & -3.262935 \\
Log likelihood & 52.28921 & Hannan-Quinn criter. & -3.431549 \\
F-statistic & 4.795030 & Durbin-Watson stat & 1.884440 \\
Prob(F-statistic) & 0.006196 & & \\
\hline \hline
\end{tabular}

Berdasarkan Tabel 3 kita mengetahui nilai prob (F-statistic) sebesar 0,00617 yang berarti nilai prob (F-statistic) $<0,05$ yang menunjukkan adanya hubungan yang signifikan antara variabel dependen dengan variabel indenpen.

Tabel 6. Uji Normalitas

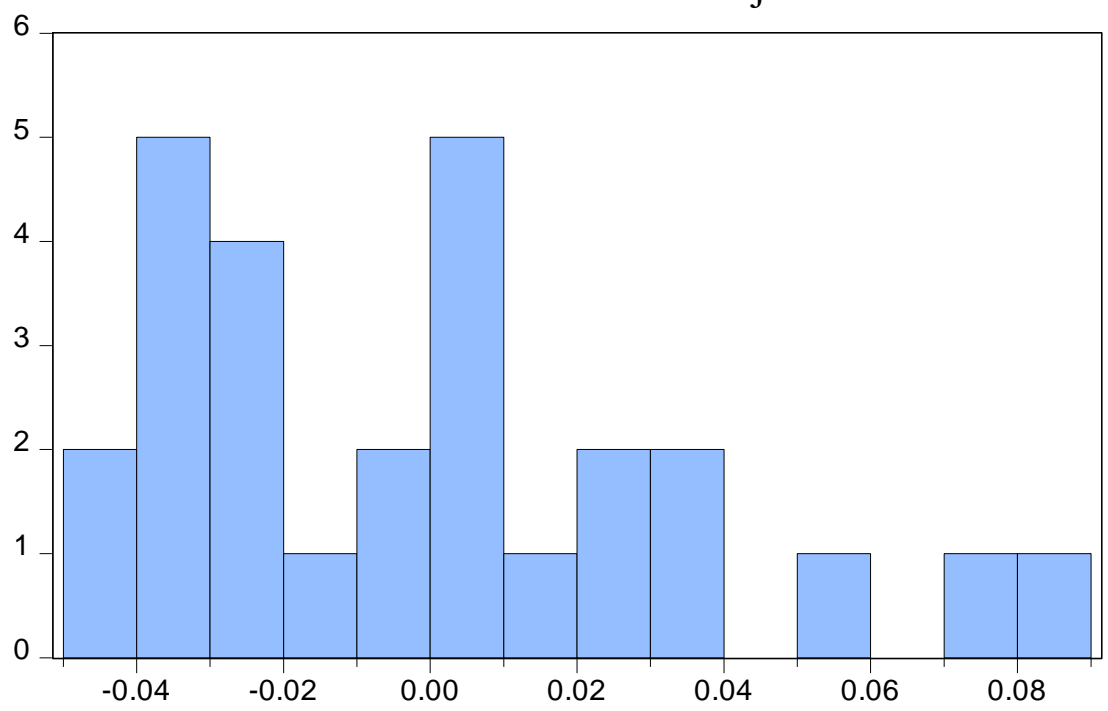

Series: Residuals

Sample 2019M01 2021M03

Observations 27

Mean

$4.47 \mathrm{e}-17$

Median

$-0.001346$

Maximum

0.088923

Minimum

$-0.048096$

Std. Dev.

0.035554

Skewness

0.832433

Kurtosis

3.004842

Jarque-Bera

3.118274

Probability

0.210318 
Hasil uji normalitas diatas menunjukkan bahwa data yang digunakan bersifat tidak normal atau dengan kata lain data yang digunakan bersifat acak, karena nilai probabilitas lebih tinggi daripada nilai 0,05 yaitu sebesar 0,210318 maka $H_{0}$ diterima. Sehingga uji normalitas ini dapat digunakan.

Tabel 7. Uji Autokorelasi

Breusch-Godfrey Serial Correlation LM Test:

\begin{tabular}{llll}
\hline \hline F-statistic & 0.630808 & Prob. F(2,20) & 0.5424 \\
Obs*R-squared & 1.602118 & Prob. Chi-Square(2) & 0.4489 \\
\hline \hline
\end{tabular}

Test Equation:

Dependent Variable: RESID

Method: Least Squares

Date: 05/26/21 Time: 13:28

Sample: 2019M01 2021M03

Included observations: 27

Presample missing value lagged residuals set to zero.

\begin{tabular}{lrcrr}
\hline \hline \multicolumn{1}{c}{ Variable } & Coefficient & Std. Error & t-Statistic & Prob. \\
\hline \hline \multicolumn{1}{c}{ C } & 0.006380 & 0.074884 & 0.085204 & 0.9329 \\
CURRENT_RATIO & 0.007068 & 0.030030 & 0.235370 & 0.8163 \\
QUICK_RATIO & -0.014245 & 0.056189 & -0.253512 & 0.8025 \\
DEBT_TO_ASET_RATIO & 0.004859 & 0.032139 & 0.151179 & 0.8813 \\
\multicolumn{1}{c}{ COVID } & $5.09 \mathrm{E}-05$ & 0.036908 & 0.001378 & 0.9989 \\
\multicolumn{1}{c}{ RESID(-1) } & 0.039154 & 0.234901 & 0.166683 & 0.8693 \\
\multicolumn{1}{c}{ RESID(-2) } & -0.268870 & 0.245494 & -1.095221 & 0.2864 \\
\hline \hline & & & \\
R-squared & 0.059338 & Mean dependent var & $4.47 \mathrm{E}-17$ \\
Adjusted R-squared & -0.222861 & S.D. dependent var & 0.035554 \\
S.E. of regression & 0.039317 & Akaike info criterion & -3.415927 \\
Sum squared resid & 0.030916 & Schwarz criterion & -3.079970 \\
Log likelihood & 53.11502 & Hannan-Quinn criter. & -3.316030 \\
F-statistic & 0.210269 & Durbin-Watson stat & 2.062305 \\
Prob(F-statistic) & 0.969325 & & \\
\hline
\end{tabular}

Berdasarkan hasil uji Autokorelasi dapat diketahui nilai chi-square sebesar 0,4489 yang menunjukkan data tidak terdapat masalah autokorelasi karena nilai chi-square $>0,05$.

Tabel 8. Uji Heterokedastisitas

Heteroskedasticity Test: Breusch-Pagan-Godfrey

\begin{tabular}{llll}
\hline \hline F-statistic & 2.456765 & Prob. F(4,22) & 0.0757 \\
Obs*R-squared & 8.336637 & Prob. Chi-Square(4) & 0.0800 \\
Scaled explained SS & 5.548286 & Prob. Chi-Square(4) & 0.2355 \\
\hline
\end{tabular}


Berdasarkan hasil uji heteroskedastisitas dapat diketahui nilai probabilitas chi-square sebesar 0,0800 yang berarti nilai probabilitas chi-square > 0,05 yang menunjukkan data bersifat homokedastisitas.

\section{DISKUSI}

Current Ratio (CR) berpengaruh terhadap Return on Assets (ROA). Menurut hasil penelitian diatas, current ratio merupakan variabel yang mempunyai pengaruh positif dan signifikan terhadap return on assets. Hal ini terjadi karena perusahaan mempunyai aset yang cukup untuk membiayai hutang-hutang wajib perusahaan.

Hasil penelitian didukung oleh penelitian (Borhan et al., 2014). meneliti hubungan current ratio terhadap kinerja perusahaan. Pada penelitian tersebut ditemukkan bahwa current ratio mempunyai pengaruh yang sangat penting sehingga perubahan yang terjadi akan memberikan dampak yang besar bagi perusahaan.

Hubungan positif dan signifikan antara current asset terhadap return on assets diperoleh karena perusahaan mempunyai nilai aset lancar yang lebih besar dibandingkan hutang lancarnya. Agar dapat mempertahankan nilai current assets maka perusahaan diharapkan untuk menghindari pembiayaan jangka pendek maka, pertumbuhan jangka pendeknya akan meningkat. Dengan menurunya biaya bunga maka akan meningkatkan laba.

Quick Ratio (QR) berpengaruh terhadap Return on Assets (ROA). Quick ratio mempunyai hubungan yang signifikan tetapi berpengaruh negatif pada perusahaan, dengan kata lain, quick ratio perusahaan saat ini memberikan pengaruh yang kurang baik bagi perusahaan.

Hasil penelitian yang dilakukan bertentangan dengan hasil penelitian yang dilakuakn (Kantakji et al., 2020). Dimana hasil penelitian tersebut menemukan hubungan signifikan diantara rasio likuiditas terhadap kinerja keuangan.

Quick ratio bersifat negatif dikarenakan perusahaan terlalu banyak memegang aset yang liquid sehingga perusahaan hanya mampu membayar hutang-hutang jangka pendeknya, tetapi akan sulit untuk membayar hutang jangka panjangnya sehingga perusahaan lebih baik menurunkan nilai aset lancar yang paling liquid sehingga perusahaan dapat memanfaatkan aset lancar untuk membayar hutang untuk jangka yang lebih panjang.

Debt to Assets Ratio (DAR) berpengaruh terhadap Return on Assets (ROA). Berdasarkan hasil penelitian diatas debt to assets ratio mempunyai hubungan negatif dan tidak signifikan. Debt to assets ratio tidak mempunyai pengaruh yang sangat berpengaruh bagi perusahaan namun pengaruh ini dapat memberikan dampak buruk bagi perusahaan.

Hal yang didapat pada penelitian ini bertentangan dengan penelitian sebelumnya yang telah dilakukan oleh (Borhan et al., 2014). Mengukur hubungan rasio leverage terhadap kinerja keuangan perusahaan dengan menggunakan debt to assets ratio sebagai alat ukurnya. Pada penelitian ini menemukan hubungan negatif dan signifikan antara rasio leverage terhadap kinerja keuangan perusahaan, dan penelitian (Zeitun dan Saleh, 2015). Meneliti hubungan rasio leverage terhadap kinerja keuangan dan memperoleh hasil penelitian bahwa hubungan rasio leverage terhadap kinerja keuangan bersifat signifikan dan 
negatif. Dimana debt to assets mempunyai hubungan yang signifikan namun negatif, karena perusahaan perlu membutuhkan modal dari hutang namun apabila nilai debt to assets ratio semakin tinggi maka nilai hutang jangka panjang akan meningkat dan akan muncul peluang gagal untuk membayar hutang tersebut.

Ketidaksignifikan antara debt to assets ratio dan return on assets disebabkan karena perusahaan memperlukan hutang untuk menjadi modal perusahaan dan nilai debt to assets ratio cenderung tidak terlalu besar sehingga perusahaan masih dapat membayar hutanghutang tersebut akan tetapi, apabila nilai debt to assets meningkat maka akan memberikan pengaruh buruk bagi perusahaan karena nilai hutang perusahaan akan meningkat sehingga akan menimbulkan kesulitan untuk membayar hutang tersebut. Perusahaan lebih baik tidak menambah hutang-hutang jangka panjang karena peningkatan hutang-hutang jangka panjang akan memberikan kendala untuk pembayaran.

COVID berpengaruh terhadap Return on Assets (ROA). Menurut penelitian diatas, kita mengetahui COVID menunjukkan ada hubungan yang signifikan dan negatif antara COVID terhadap return on assets. Dimana keberadaan COVID menyebabkan pengaruh buruk bagi kinerja perusahaan. Hal ini disebabkan karena Pembatasan Sosial Berskala Besar atau yang disebut PSBB, sehingga menyebabkan menurunnya angka kunjungan sekitar 23\% penduduk ke pusat perbelanjaan dan $29 \%$ ke perkantoran (Soraya, 2021). Penurunan angka penduduk ke perkantoran menyebabkan perusahaan tidak dapat beroperasi secara maksimum yang dikarenakan pembatasan jumlah karyawan. Penurnan angka penduduk ke pusat pembelanjaan juga menyebabkan penurunan pemesanan dari pusat pembelanjaan yang menyebabkan pendapatan perusahaan menurun. Perusahaan tidak dapat menghindari pandemi akan lebih baik perusahaan mencari alternatif yang lebuh efisien untuk meningkatkan pendapatan dan laba pada masa pandemi COVID-19 ini.

\section{KESIMPULAN}

Berdasarkan hasil penelitian yang telah dilakukan kita dapat meenyimpulkan bahwa: Terdapat pengaruh positif dan signifikan antara current ratio terhadap return on assets pada PT Multisport Indonesia periode Januari 2019 - Maret 2021. Terdapat pengaruh negatif dan signifikan antara quick ratio terhadap return on assets pada PT Multisport Indonesia periode Januari 2019 - Maret 2021. Terdapat pengaruh negatif dan tidak signifikan antara rasio leverage yang diukur dengan debt to assets ratio terhadap kinerja keuangan yang diukur dengan return on assets pada PT Multisport Indonesia periode Januari 2019 - Maret 2021. Terdapat hubungan signifikan antara COVID-19 yang merupakan variabel dummy terhadap kinerja keungan yang diukur dengan return on assets pada PT Multisport Indonesia periode Januari 2019 - Maret 2021.

Terkait dengan adanya beberapa keterbatasan dan hasil dari penelitian ini, maka saran yang dapat diberikan adalah sebagai berikut: Peneliti menyarankan kepada PT Multisport Indonesia untuk mengurangi pembayaran-pembayaran jangka pendek. Contoh transaksitransaksi yang melakukan pembayaran cash dalam jumlah besar dikurangi. Peneliti selanjutnya dapat melakukan penelitian setelah data perusahaan lebih dari 5 tahun. Supaya penelitian lebih berkembang, maka disarankan pada penelitian selanjutnya ditambahkan variabel-variabel yang memiliki pengaruh terhadap kinerja keuangan. 


\section{DAFTAR PUSTAKA}

Bhama, V., Jain, P. K., and Yadav, S. S. (2016). Testing the pecking order theory of deficit and surplus firms: Indian evidence. International Journal of Managerial Finance, 12(3), 335-350. https://doi.org/10.1108/IJMF-06-2014-0095.

Borhan, H., Naina Mohamed, R., and Azmi, N. (2014). The impact of financial ratios on the financial performance of a chemical company. World Journal of Entrepreneurship, Management and Sustainable Development, 10(2), 154-160. https://doi.org/10.1108/wjemsd-07-2013-0041.

Corelli, A. (2019). Chapter 14 Liquidity Risk. 4, 331-367.

Dalnial, H., Kamaluddin, A., Sanusi, Z. M., and Khairuddin, K. S. (2014). Detecting Fraudulent Financial Reporting through Financial Statement Analysis. 2(1), 17-22. https://doi.org/10.12720/joams.2.1.17-22.

Danso, A., Lartey, T. A., Gyimah, D., and Adu-Ameyaw, E. (2020). Leverage and performance: do size and crisis matter? Managerial Finance, 47(5), 635-655. https://doi.org/10.1108/MF-10-2019-0522.

Kasmir. (2016). Pengantar Manajemen Keuangan. In Prenada Media. Prenada Media.

Franco Modigliani and Merton H. Miller. (1958). The Cost of Capital, Corporation Finance and the Theory of Investment. The American Economic Review, Vol. 48, N, 37.

Goel, U., Chadha, S., and Sharma, A. K. (2015). Operating liquidity and financial leverage : Evidences from Indian machinery industry. Procedia - Social and Behavioral Sciences, 189, 344-350. https://doi.org/10.1016/j.sbspro.2015.03.230.

Horvath, R., and Seidler, J. (2013). How bank competition influence liquidity creation Institute for Economies in Transition.

Kantakji, M. H., Abdul Hamid, B., and Alhabshi, S. O. (2020). What drives the financial performance of general takaful companies? Journal of Islamic Accounting and Business Research, 11(6), 1301-1322. https://doi.org/10.1108/JIABR-06-2018-0077

Kuchler, A. (2020). Leverage, investment, and recovery from a financial crisis: the role of debt overhang. Studies in Economics and Finance, 37(1), 143-159. https://doi.org/10.1108/SEF-04-2019-0158.

Kurniati, S. (2019). Stock returns and financial performance as mediation variables in the influence of good corporate governance on corporate value. Corporate Governance (Bingley), 19(6), 1289-1309. https://doi.org/10.1108/CG-10-2018-0308.

Marfianto, dan Nuryasman, M. (2019). Pengaruh Rasio Keuangan , Tata Kelola Perusahaan Terhadap Kesulitan Keuangan Pada Perusahaan Pertambangan. Jurnal Manajetial Dan Kewirausahaan, I(4), 862-871.

Marginingsih, R. (2017). Penilaian Kinerja Perusahaan Dengan Menggunakan Analisa Rasio Keuangan Pada Perusahaan Telekomunikasi Di Indonesia. XVII(1), 14-21.

Mulyawan, S. (2015). Manajemen Keuangan. Pustaka Setia.

Nikolov, B. (2013). Dynamic Corporate Liquidity *.

Nuryasman, M., Amelinda, R., and Nuringsih, K. (2020). The Propensity for Social Entrepreneurship During the Coronavirus Outbreak. Jurnal Manajemen, 24(2), 174. https://doi.org/10.24912/jm.v24i2.637.

Pokharel, K. P., Regmi, M., Featherstone, A. M., and Archer, D. W. (2019). Examining the financial performance of agricultural cooperatives in the USA. Agricultural Finance 
Review, 79(2), 271-282. https://doi.org/10.1108/AFR-11-2017-0103.

Pranita, E. (2020). Diumumkan Awal Maret, Ahli: Virus Corona Masuk Indonesia dari Januari. Kompas.Com. https://www.kompas.com/sains/read/2020/05/11/130600623/diumumkan-awalmaret-ahli--virus-corona-masuk-indonesia-dari-januari.

Samben, R., dan Pattisahusiwa, S. (2017). Analisis kinerja keuangan. 14(1), 6-15.

Soraya Novika. (2021). Setahun Corona di RI, Ini 3 Dampaknya ke Ekonomi. DetikFinance. https://finance.detik.com/berita-ekonomi-bisnis/d-5479673/setahun-corona-di-ri-ini3-dampaknya-ke-ekonomi.

Stewart, C. (1984). NBER Working Paper it11393 Capital. 1393.

Tampubolon, lambok D. (2015). Analisis Pengaruh Rasio .... 12(1), 1-12.

Widnyana, I. W., Wiksuana, I. G. B., Artini, L. G. S., and Sedana, I. B. P. (2020). Influence of financial architecture, intangible assets on financial performance and corporate value in the Indonesian capital market. International Journal of Productivity and Performance Management, 1999. https://doi.org/10.1108/IJPPM-06-2019-0307.

Zainal, I., dan Marlius, D. (2016). PT . PEGADAIAN CABANG ULAK KARANG. 1-10.

Zeitun, R., and Saleh, A. S. (2015). Dynamic performance, financial leverage and financial crisis: Evidence from GCC countries. EuroMed Journal of Business, 10(2), 147-162. https://doi.org/10.1108/EMJB-08-2014-0022.

\section{Ucapan Terima Kasih}

Disampaikan ucapan terima kasih kepada Dosen Pembimbing yang telah membimbing hingga publikasi. 